\title{
КОМПОНЕНТИ ГРОМАДЯНСЬКОЇ ІДЕНТИЧНОСТІ ТА ОСОБЛИВОСТІ ÏХ РОЗВИТКУ
}

УДК:159.922.4(477)-053.6

\section{Зайцева Юлія}

Студент магістратури, Мелітопольський державний педагогічний університет імені Богдана Хмельницького, м. Мелітополь (Украӥна)

\section{Прокоф'єва Олеся Олексївна}

Кандидат психологічних наук, дочент, Мелітопольський державний педагогічний університет імені Богдана Хмельницького, м. Мелітополь (Украӥна)

\section{Прокоф'єва Ольга Анатолї̈на}

Старший викладач кафедри анатомї та фізіології людини та тварин, Мелітопольський державний педагогічний університет імені Богдана Хмельницького, м. Мелітополь (Украӥна)

\begin{abstract}
Анотація. Автори статті досліджують компоненти громадянської ідентичності в підлітковому віці. Громадянська ідентичність розглядається як компонент самоусвідомлення особистості, яка є компонентом соціальної ідентичності. Авторами аналізуються поняття «громадянська ідентичність», «приналежність», «нація», «група». Проведений аналіз останніх наукових досліджень з даної тематики. Охарактеризована та досліджена громадянська ідентичність у підлітковому віц̧і, встановлені иляхи ї̈ становлення через структурні компоненти. В статті представлена розроблена тренінгова програма для підліткового віку. Описується особливості використанні в розвивальній роботі з підлітками інноваційні методи арт-терапевтичні, психодраматичні, дискусійні тощо. Впроваджена тренінгова програма може бути використана для встановлення рівня громадянської ідентичності, проведення психокорекційної та розвивальної роботи.
\end{abstract}

Ключові слова: нація, група, громадянство, громадянська ідентичність, ідентичність, соціальна ідентичність, толерантність, ијіності.

Постановка проблеми: Надзвичайно ні становлення громадянської ідентичності. актуальною проблемою в Україні $є$ на сьогод- 
тичного розвитку, гостро постало питання єдності держави та збереження територіальної цілісності. У зв'язку с цим актуалізується питання громадянської ідентичності, адже саме вона $є$ чинником, який сприяє самоорганізації індивідів, які об'єднані належністю до однієї держави як сукупність «ми», що підтримує єдину систему уявлень, переконань про державу, країну та самого себе як члена суспільства.

Метою статті $\epsilon$ виявлення психологічних особливостей громадянської ідентичності у підлітковому віці, дослідження понять «група», «нація», громадянство» та встановлення їх відмінності від поняття «громадянська ідентичність», обгрунтування тренінгової програми для розвитку громадянської ідентичності у підлітковому віці.

Аналіз останніх досліджень і публікацій. Вивченням громадянської ідентичності займались вітчизняні та зарубіжні автори. Ю. Габермас вважає, що громадянське суспільство це публічна сфера, в якій узгоджується суспільна думка з громадкістю і транслюється до політичної сфери. В. Степаненко розглядає причини психологічно-емоційного несприйняття громадянської ідентичності українців [2, c. 40].

Компоненти громадянської ідентичності вивчали М. Барет, М. Беннет, А. М. Березик, Л. I. Божович, М. Й. Боришевський, Ш. Берн, Б. А. Вяткін, М. Р. Гінзбург, В. В. Горбунова,
П. І. Гнатенко, Е. Еріксон, В.А. Кирсанов, I. С. Кон, Дж. Марсія. А. Р. Аклаєв, Л. М. Добіжева, В. В. Коротєєва розглядали громадянську ідентичність через ототожнення індивіда зі спільностями на рівні вищих диспозицій [8]. Сучасні українські дослідники також займаються проблемою громадянської ідентичності: О. Ю. Михайлова, Н. І. Пилат, В. М. Горлова, Б. С. Черкес, О. Р. Омельчук, В. П. Землюк, M. I. Обушний, I. Ю. Вільчанська, В. Е. Верлока, О. Л. Добржанська, Т. С. Колосок.

Дослідження А. Д. Андреєвої, Л. І. Божович, Л. С. Виготського, I. В. Дубровіної, К. Левіна, Ж. Піаже, О. М. Прихожан, Д. І. Фельдштейна та інших свідчать, що підлітковий вік є періодом самовизначення, теоретизування та розвитку рефлексії, становлення громадянської ідентичності, що дає особистості можливість обмірковувати, структурувати, планувати свій життєвий шлях [7].

Громадянська ідентичність, на думку В.Т. Степаненка, це ототожнення себе зі спільнотою громадян національно-державного утворення або феномен свідомого та активного громадянства, усвідомлення себе членом громадянського суспільства. Часто громадянська ідентичність розглядається компонентом територіальної ідентичності [3]. На думку Б. Андерсен, Е. Геллнер А. Геллнер, Е. Сміт, «громадянська ідентичність» може бути аналогом «національної ідентичності», коли наці- 
ональна ідентичність розглядається в межах нації як співгромадянства, спільноти, організованих за державно-політичною ознакою. Вони говорять про особливості інтеграції окремих індивідів в громадянську спільноту шляхом усвідомлення своєї приналежності до неї [6]. В такому разі громадянську ідентичність розглядають як компонент соціальної ідентичності, індивідуального знання про те, що індивід належить до певної соціальної групи разом $з$ емоційним і ціннісним компонентом, стверджує Г. Теджфел [7, с. 238].

Виділення невирішених раніше частин загальної проблеми, яким присвячується стаття. Громадянське суспільство стає незамінним партнером держави у формуванні та відстоюванні нової ідентичності, в побудові їі інститутів, у подоланні опору приватизованих інститутів колишньої ідентичності, тому наше дослідження є актуальним в сучасному суспільстві та може бути корисним не тільки практикуючим психологам, але й соціальним працівникам, класним керівникам і вихователям. Розроблена i апробована розвивальна тренінгова програма може бути використана у роботі психолога школи для розвитку громадянської ідентичності у підлітковому віці.

Виклад основного матеріалу. Громадянську ідентичність формують наступні чинники: спільне історичне минуле відображене в легендах, символах та міфах; безпосередньо сама назва спільності; одна мова, як засіб комунікації; спільна культура; переживання сус- пільством спільних емоційних станів, пов'язаних 3 реальною ситуацією в країні. Формуванню громадянської ідентичності сприяють різні інститути соціалізації (культура, спорт, школа, ЗМІ, громадські організації) та первинне середовище - сім'я, яка формує уявлення про країну та Батьківщину, рідну культуру та поведінку.

Для формування громадянської ідентичності потрібно сформувати наступні структурні компоненти:

Когнітивний (пізнавальний) - це достатні знання про владу, символіку держави, правові організації суспільства, суспільнополітичні події, вибори, лідерів політики, партій та їх програми, знання свої прав та обов'язків, розвиток інтелектуальної та моральної сфери.

Емоційно-оцінний - готовність та бажання взяти участь в житті країни, наявність власного ставленні, здатність до рефлексії та емпатії.

Ціннісно-орієнтовний - толерантність, повага прав людей та самоповага, повага та прийняття правових основ суспільства та держави.

Діяльнісний (поведінковий) - брати відповідальність за прийняття рішень, брати участь у громадському житті закладів освіти та житті країни, мати самостійність у виборі рішень, здатність протистояти асоціальним діям та вчинкам, наявність критичного мислення. 
Формування громадянської ідентичності включає в себе декілька компонентів [4]:

Знання - включає в себе, знання історії та культури власного рідного краю, політичні, основні знання про соціальну сферу суспільства, знання з етики та соціальної екології.

Навички та вміння - включає в себе, вміння критично мислити 3 використанням широкого кола джерел, аналізувати інформацію та критично оцінювати іiі, розуміння соціальних проблем та їх сутність, приймання обгрунтованих рішень та брати на себе відповідальність, вміння брати на себе відповідальність, вміння реалізувати громадські та індивідуальні права та обов'язки, вміння використовувати механізми захисту прав людини на всіх існуючих рівнях, вміння працювати в групі, відстоювати і висловлювати власну думку, вміння слухати інших та виділяти стереотипи, навички толерантності, забобони та упереджену думку.

Цінності - включає в себе, формування наступних цінностей: гуманність, повага прав і свобод людей, самовизначення, повага гідності, норм і правил сучасної демократіï, дотримання національних традицій та культур, загальнолюдських цінностей, патріотизм, готовність до компромісу, правдивість тощо [1].

Громадянське виховання має на основі ідеї повноцінної участі людини під час вирішення суспільних завдань суспільства.
В пострадянських країнах часто громадянське суспільство мало розвинено не знає власних стандартів, ідеалів та цінностей, це призводить до відсутності об'єктів для ідентифікації. В таких випадках об'єктами для ідентифікації можуть стати, історичні, літературні персонажі та герої казок в їх тексті повинні бути розкриті загальнолюдські цінності, цивільні та культурні еталони. В сучасному суспільстві постійно відбуваються зміни, в них можуть змінюватися і ціннісні орієнтири, але в мистецтві та культурі вони залишаються незмінними навіть при зміні світогляду та побуту. Культура може стати точкою опори, для відновлення цілісності в сприйнятті себе та світу. Установлення зв'язку з культурним минулим, дає можливість приймати нові ідеї та форми активної діяльності [2].

Важливою умовою при формуванні громадянської ідентичності є позитивна етнічна ідентичність, вона може забезпечити толерантні взаємини між представниками різних етнічних групи в сучасному полікультурному суспільстві. Дана етнічна ідентичність може бути сформована тільки на основі прийняття власної етнічної приналежності і формування позитивного ціннісного ставлення до етнічних особливостей однолітків. Значущою проблемою становлення громадянської ідентичності є їі збіг з процесом соціалізації в цілому. Тому, в закладах освіти, в заходах щодо формування громадянсь- 
кої ідентичності є формування важливих характеристик особистості, таких як: патріотизм, прийняття вже установлених провідних цінностей своєї національної культури; готовність до співпраці з представниками різних етносів та громад, що мають власні культурні та релігійні переконання; формування в свідомості учня відчуття власної приналежності до долі людства [7, с. 242].

Наша тренінгова програма має назву «Я - свідомий українець» і має на меті сприяти становленню громадянської ідентичності у підлітковому віці через усвідомлення власної приналежності до свого народу та розвиток толерантності до інших народів. Нами було висунуто такі завдання для розвитку громадянскої ідентичності: розвиток ціннісного компоненту: свобода, порядність, процвітання і безпека країни, любов до Батьківщини та людей, самоцінність, повага до усіх етносів та громад, а також розвиток толерантності до інших громадян. Розвиток когнітивного компоненту - знання про владу, символіку та державу, свої права та обов'язки, моральний та інтелектуальний розвиток. Емоційно-оцінний компонент - розвиток рефлексії та критичного мислення, бажання брати участь в житті країни та суспільства. Діяльнісний компонент: спілкування надає індивіду більше можливостей набути знання про особливості своєї та інших громадянських груп, сприяє розвитку розуміння та формування комунікативних навичок, дає змогу брати відповідальність за прийняття рішень та брати активну участь в громадському житті. Після детального вивчення існуючих програм було обрано оптимальні методи: арт-терапія, дискусія, психогімнастика, медитації-візуалізації, рольова гра, ділова гра, елементи психодрами і соціодрами.

Дана програма розрахована на 30 годин, 15 занять тривалістю по 2 години з частотою зустрічей 2 рази на тиждень. Програма структурована та має три блоки: вступ (перше та друге заняття), основний блок (з третього по тринадцяте заняття), заключна частина (чотирнадцяте та п'ятнадцяте заняття). Кожне iз занять має власну мету, яка в свою чергу підпорядковується головній меті тренінгу.

Структура тренінгової програми:

Заняття 1-2. Тема: «Знайомство». Мета: визначення мети, завдань, принципів роботи у групі. Прийняття правил роботи в групі. Створення атмосфери спільності, довіри і взаєморозуміння. Налаштування на подальшу роботу. Вправи: Заняття 1 - «Вступне коло», «Прийняття правил роботи в групі», «Асоціація 3 тематичною роботою в групі», «Твір на задану кінцівку», «Паперові м’ ячі», «Завершальне коло». Заняття 2 - «Вступне коло», «Три якості, які...», «Конверт суджень», «Життєва позиція», «Завершальне коло».

Заняття 3. Тема: «Самооцінка». Мета: розвиток уявлень про себе, формування адекватної позитивної самооцінки. Вправи: «Вступне коло», «Реклама - двигун тренінгу», 
«Частини мого «Я»», «Чорне та біле», «Перехрестя», «Завершальне коло».

Заняття 4. Тема: «Що собою представляє громадянська ідентичність». Мета: дослідження власної громадянської ідентичності. Вправи: «Вступне коло», «Моментальна фотографія», «Що таке громадянська ідентичність?», «Моя громада», «Завершальне коло».

Заняття 5. Тема: «Права та обов'язки». Мета: усвідомлення своїх прав та обов'язків у суспільстві. Ширше знайомство з наявнім правовим урегулюванням в країні. Вправи: «Вступне коло», «В дитинстві я хотів бути», «Мої права та обов'язки», міні-лекція «Правова регуляція», «Мої права та обов'язки», «Завершальне коло».

Заняття 6. Тема: «Символічне відображення себе в державі» Мета: дослідження символів держави та свої власних, розвиток діяльнісного компоненту ідентичності. Вправи: «Вступне коло», «Передача рухів по кругу», «Знайди пару» «Створення власного герба», «Що в ньому нового», «Завершальне коло».

Заняття 7. Тема: «Мої цінності». Мета: Розвиток цінностей та ціннісних уявлень власної громади. Вправи: «Вступне коло», «Пересядьте ті, хто ...», «Цінності», «Громадянські цінності», «Завершальне коло».

Заняття 8. Тема: «Толерантність у нашому житті». Мета: розвиток толерантного відношення до власного та інших народів. Вправи: «Вступне коло», «Передай предмет»,
«Рольова гра «Суд»», «Розвиток толерантності», «Хто є хто?», «Чарівна країна», «Завершальне коло», домашнє завдання.

Заняття 9. Тема: «Я - свідомий представник свого народу». Мета: розвиток образу власної громадянської ідентичності. Вправи: «Вступне коло», «Мої ідеали», «Мандала як символ моєї громади», «Багатолика Україна», «Медитація візуалізація. Чайка, на якій я пливу», «Завершальне коло».

Заняття 10. Тема: «Межі мого «Я»». Мета: постановка та усвідомлення своїх кордонів та кордонів інших людей. Вправи: «Вступне коло», «Чотири кута - чотири вибори», «Розповідь від імені», «Мапа мого життя», «Завершальне коло».

Заняття 11. Тема: «Державні символи». Мета: підвищення громадянської самосвідомості, розвиток позитивного становлення до державної символіки. Вправи: «Вступне коло», «Афоризми та прислів'я», «Державні символи», «Колаж - створення власного символу», «Рядок власного гімну», «Завершальне коло».

Заняття 12. Тема: «Головна мета - вижити». Мета: постановка усвідомлення загальних правил поведінки у суспільстві та під час взаємодії 3 представниками інших громад. Вправи: «Вступне коло», «Розвідник», «Острів», «Завершальне коло».

Заняття 13. Тема: «Професійний потенціал». Мета: формування активності в саморозвитку. Вправи: «Вступне коло», «Минуле - 
Розподіл середніх показників за шкалами САТ

у студентів $(n=243)$

\begin{tabular}{|l|c|c|c|c|c|}
\hline \multirow{2}{*}{ Шкали } & \multicolumn{5}{c|}{ Одержані результати (\%) } \\
\cline { 2 - 6 } & I курс & II курс & III курс & V курс & Уся \\
\hline Компетентність у часі & & & & 44,96 \\
\hline Підтримка & 46,14 & 45,58 & 42,23 & 44,69 & 49,75 \\
\hline Ціннісна оріснтація & 47,35 & 48,58 & 50,13 & 53,80 & 50,65 \\
\hline Гнучкість поведінки & 49,90 & 48,56 & 51,74 & 52,64 & 46,67 \\
\hline Сенситивність до себе & 44,62 & 47,39 & 47,96 & 48,08 & 49,82 \\
\hline Спонтанність & 49,34 & 48,90 & 52,13 & 49,64 & 59,06 \\
\hline Самоповага & 45,79 & 49,49 & 52,48 & 50,95 & 52,34 \\
\hline Самоприйняття & 51,43 & 54,54 & 51,81 & 52,19 & 46,29 \\
\hline Уявлення про природу людини & 45,22 & 46,33 & 44,90 & 48,72 & 52,95 \\
\hline Синергія & 54,82 & 48,47 & 51,30 & 55,16 & 51,74 \\
\hline Прийняття агресіі & 50,66 & 49,37 & 49,48 & 56,75 & 48,52 \\
\hline Контактність & 48,27 & 47,66 & 48,88 & 49,32 & 49,52 \\
\hline Пізнавальні потреби & 50,68 & 49,11 & 45,60 & 50,95 & 43 \\
\hline Креативність & 42,01 & 42,50 & 38,86 & 47,66 & 47,56 \\
\hline
\end{tabular}

сучасне - майбутнє», «Групова дискусія», «Перетворюємо проблеми в цілі», «Завершальне коло».

Заняття

14-15.

Тема:

«Самовдосконалення». Мета: розвиток мотивації самовдосконалення і самоактуалізації. Завершення тренінгу, прощання з учасниками. Вправи: Заняття 14 - «Вступне коло», «Групова дискусія», «Кіно», «Лист з майбутнього», «Завершальне коло». Заняття 15 «Вступне коло», створення скульптури «Ми українці», «Валіза ва дорогу», «Аплодисменти», «Завершальне коло».

Вступні заняття направлені на визначення мети, завдань, принципів роботи у гру- пі, створення атмосфери спільності, довіри $\mathrm{i}$ взаєморозуміння, налаштування на подальшу роботу. Основний блок складається 311 занять, які в свою чергу розвивають уявлення про себе, формують адекватну позитивну самооцінку, забезпечують розвиток цінностей та ціннісних уявлень власної громади, толерантного ставлення до власного та інших громад, розвиток образу власної громади, усвідомлення власних прав та обов'язків, прилучення до державних символів країни тощо. Заключний блок складається 3 двох занять, які направлені на формування активності та саморозвитку дітей, на розвиток мотивації самовдосконалення і самоактуалізації, завершення тренінгу, 
прощання з учасниками.

В нашій тренінговій програмі ми підібрали комплекс методик з залученням технік [5], які направлені на розвиток умов громадянської ідентичності, а саме - усвідомлення свого членства в громадянській групі, разом 3 цінностями та емоційним значенням, приписаним цій громаді, механізмів ідентифікації, інтерналізації та рефлексії, усвідомлення соціального досвіду. При формуванні ідентичності задіяні процеси самопізнання, самооцінки, самопрезентації, накоплення знань, оцінок та способів поведінки, що планується розвинути в нашій тренінговій програмі.

Під час тренінгу застосувався різний інструментарій, наприклад, національна іграшка для вступного кола, громадянські мандали, арт-терапетичні техніки з застосуванням олівців, фарб та пастелі. Були використані рольові та ділові ігри для програвання та постановки власних кордонів особистості, фотографії відомих людей, проблемні ситуації та факти з літератури для обговорення під час дискусії, деякі заняття мали у своїй структурі домашні завдання для учасників тренінгу. Після деяких занять тренінгу для дітей пропонувалися медитації-візуалізації, які направлені на релаксацію, активізацію життєвих сил, знаходження балансу всередині себе.

В результаті впровадження протягом 2015-2017 років, дана тренінгова програма показала свою ефективність. В експерименті брали участь учні підліткового віку в кількості
60 осіб. Для діагностики був використаний комплекс методик: опитувальник «Хто Я?», методика Дж. Фінні в модифікації М.В. Шакурова, методика «Типовий українець», опитувальник конативної складової національної ідентичності, опитуальник «Три компонентів ідентичності». Після проведення розвивального тренінгу та повторної діагностики, можна судити про статистично значущий $(\mathrm{p}<0,01)$ piвень розвитку кожного компоненту громадянської ідентичності.

Зокрема, в експериментальній групі помітне покращення рівню рефлексії: високий рівень до тренінгу - 39,96 \% респондентів, після тренінгу - 79,92 \%, низький рівень рефлексії до тренінгу $-6,66 \%$, після тренінгу - $0 \%$. За компонентами громадянської ідентичності: високий рівень когнітивного компоненту до експерименту - 59,94 \%, після експерименту 66,6 \%, низький рівень - 1,66 \%, після експерименту - $0 \%$; високий рівень афективнооцінного компоненту до експерименту - 73,26 $\%$, після експерименту - 79,92 \%, низький рівень відсутній; високий розвиток когнітивного компоненту до тренінгу - 53,28 \%, після $66,6 \%$, конативний компонент на високому рівні розвитку до тренінгу у 59,94 \%, після тренінгу - 79,92 \%. Високий рівень становлення громадянської ідентичності до експерименту $-19,98 \%$, після - 26,64 \%, низький до експерименту - 19,98\%, після експерименту - 6,6 \%. Переважна більшість має середній рівень, що свідчить про знаходженні на рівні станов- 
лення громадянської ідентичності. Відстоювати інтереси свого народу до тренінгу готові 39,96 \% респондентів, після тренінгу - 53,28 $\%$.

Висновки. Громадянська ідентичність формується шляхом розвитку іiї компонентів когнітивного, емоційно-оцінного, ціннісно орієнтаційного та діяльнісного. Виховання цих компонентів слугує меті становлення повноцінної участі людини в вирішенні суспільних завдань суспільства. Важливою умовою при формуванні громадянської ідентичності $€$ позитивна етнічна ідентичність, вона може забезпечити толерантні взаємини між представниками різних етнічних групи в сучасному полікультурному суспільстві. Розроблена нами тренінгова програма $є$ успішною та приводить до позитивних змін. Спостерігається усвідомлене ототожнення себе с власною громадою, усвідомлюється важливість ідентифікації, з'являється розуміння прав та обов'язків, розвивається розуміння державної символіки. Респонденти швидко включались в процес тренінгу, виявляли активність та зацікавленість під час виконання тренінгових вправ.

Перспективи подальших розвідок у даному напрямі. Полягають у розробці спеціальної просвітницької програми для учнів 111 класів 3 теми громадянської ідентичності, метою якої буде допомога у виявленні власної громадянської ідентичності, розвиток толерантності до інших народів, етносів та націй, формування громадянської позиції українців зі школи.

\section{Перелік використаних джерел:}

1. Байбородова Л. В. Психолого-педагогическое сопровождение образовательной деятельности обучающихся / Л.В. Байбородова, Л.Н. Серебреников. - Ярославль: Канцлер, 2008. - 168 c.

2. Гаджієв К. С. Концепція громадянського суспільства: ідейні витоки і основні віхи формування / К.С. Гаджієв // Питання філософії - 2010. - № 3. - С. 3850.

3. Енииклопедія Сучасної України. Том 6.: энциклопедия / керів. роботи М. Г. Железняк. - К.: НАН України, 2006. - $711 \mathrm{c}$.

4. Заступова I. В. Формування громадянськості школярів у діяльності класного керівника: Дисс.... Канд. пед. наук. - Самара, 2007. - 183 с.

5. Рудестам К. Групповая психотерапия / К. Рудестам; пер.с англ. А. Голубев. - СПб. : Питер, 1998. - 384 с.

6. Соиіально-психологічний вимір демократичних перетворень в Україні / За ред. С.Д. Максименка, В.Т. Циби, Ю.Ж. Шайгородського. - К.: Український центр політичного менеджменту, 2003. - 512 с.

7. Стасюк Г. Особливості формування етнокультурної та громадянської ідентичності в освітньому середовищі / Г. Стасюк // Проблеми гуманітарних наук. Психологія. - 2015. - Вип. 37. - С. 237-246.

8. Юшин М. Молодежный парламентаризм и формирование гражданской идентичности / М. Юшин. // Обозреватель. - 2007. - № 7. - С. 26 - 35 .

\section{References (Transliteration):}

1. Bayborodova L. V. (2008). Psihologo-pedagogicheskoe soprovozhdenie obrazovatelnoy deyatelnosti obuchayuschihsya [Psychological and pedagogical support of educational activity of the students]. - Yaroslavl : Kantsler [in Ukrainian]. 
2. Gadzhiev K. S. (2010). Kontseptsiya gromadyanskogo suspilstva: IdeynI vitoki i osnovni vihi formuvannya [Concept of civil society: ideological origins and basic milestones of formation] // Pitannya filosofiyi, 3, 38-50 [in Ukrainian].

3. Entsiklopediya suchasnoyi Ukrayini. Tom.6 [Encyclopedia of modern Ukraine. Tom.6]. - Kiyiv: NAN Ukrayini [in Ukrainian].

4. Zastupova I. V. (2007). Formuvannya gromadyanskostI shkolyarIv u dIyalnostI klasnogo kerIvnika [Formation of citizenship of schoolchildren in the fctivities of a classroom Leader]: Diss.... Kand. ped. nauk.- Samara [in Ukrainian].

5. Rudestam K. (1998). Gruppovaya psihoterapiya [Group psychotherapy] per.s angl. A. Golubev. - SPb. : Piter [in Russian]

6. Sotsialno-psihologichniy vimir demokratichnih peretvoren $\mathrm{v}$ Ukrayini [Socio-psychological dimension of democratic transformations in Ukraine], $\mathrm{Za}$ red. S.D. Maksimenka, V.T. Tsibi, Yu.Zh. Shaygorodskogo. - K.: Ukrayinskiy tsentr politichnogo menedzhmentu [in Ukrainian].

7. Stasyuk G. (2015). Osoblivosti formuvannya etnokulturnoyi ta gromadyanskoyi Identichnosti v osvitnomu seredovischi [Features of the formation of ethnocultural and civic identity in the educational environment] / G. Stasyuk // Problemi gumanitarnih nauk. Psihologiya, 37, 237-246 [in Ukrainian].

8. Yushin M. (2007). Molodezhnyiy parlamentarizm i formirovanie grazhdanskoy identichnosti [Youth parliamentarism and formation of civil identity] Obozrevatel, 7, 26 - 35 [in Ukrainian].

\section{Zaytseva Jullia}

Master's student, Bogdan Khmelnitsky Melitopol State Pedagogical University, Melitopol (Ukraine)

\section{Prokofieva Olesya}

Candidate of Psychological Sciences, Associate Professor, Bogdan Khmelnitsky Melitopol State Pedagogical University, Melitopol (Ukraine)

\section{Prokofieva Olga}

Senior Lecturer at the Department of Anatomy and Physiology of Human and Animals, Bogdan Khmelnitsky Melitopol State Pedagogical University, Melitopol, (Ukraine)

\section{COMPONENTS OF CIVIC IDENTITY AND PECULIARITIES OF ITS DEVELOPMENT}

\section{ABSTRACT}

The authors present the actual problem in Ukraine - the formation of civil identity. The country is experiencing a difficult period of political development, the question of the unity of the state and the preservation of territorial integrity has become acute. In this regard, the question of civic identity is sharply raised, because it is the factor that promotes the self-organization of individuals, united by belonging to one state as a set of «we», which supports a unified system of ideas, beliefs about the state, the country and itself as a member of society.

The existing scientific achievements on the declared topics are analysed. The opinions of domestic, foreign authors and contemporary Ukrainian scholars have been researched and presented. Several different definitions of the concept of «civil identity» are analysed.

It was discovered that the civic identity is identification with the community of citizens of national-state formation or the phenomenon of conscious and active citizenship, self-awareness of a member of civil society. Civic identity is often considered as a component of territorial iden- 
tity.

It is revealed that for formation of civic identity it is necessary to form the following structural components: cognitive, emotionalappraisal, value-orientation, activity (behavioural).

The authors of the article presented the developed training program «I am a Conscious Ukrainian», which aims to promote the development of civic identity in adolescence through awareness of their belonging to their nation and the development of tolerance to other nations. After detailed study of existing programs, the best methods were chosen: art therapy, discussion, psychogymnastics, meditation-visualization, roleplaying game, business game, elements of psychodrama and sociodrama.

Key words: nation, group, citizenship, civic identity, identity, social identity, tolerance, values.

\section{Зайцева Юлия}

Студентка магистратуры, Мелитопольский государственный педагогический университет имени Богдана Хмельниикого, г. Мелитополь (Украина)

\section{Прокофьева Олеся Алексеевна}

Кандидат психологических наук, доиент кафедры психологии, Мелитопольский государственный педагогический университет имени Богдана Хмельницкого, г. Мелитополь (Украина)

\section{Прокофьева Ольга Анатолиевна}

Старший преподаватель кафедры анатомии и физиологии человека и животных, Мелитопольский государственный педагогический университет имени Богдана Хмельницкого, г. Мелитополь (Украина)

\section{КОМПОНЕНТЫ ГРАЖДАНСКОЙ ИДЕНТИЧНОСТИ И ОСОБЕННОСТИ ИХ РАЗВИТИЯ}

Аннотация. Авторами представлена актуальная проблема в Украине - становление гражданской идентичности. Страна сегодня переживает сложный период политического развития, остро встал вопрос единства государства и сохранения территориальной целостности. В связи с этим встает вопрос гражданской идентичности, ведь именно она является фактором, который способствует самоорганизации индивидов, объединенных принадлежностью к одному государству как совокупность «мы», что поддерживает единую систему представлений, убеждений о государстве, страну и самого себя как члена общества.

Проанализированы существующие научные достижения в заявленной тематике. Исследованы мысли отечественных, зарубежных авторов и современных украинских ученых. Проанализированы несколько различных определений понятия «гражданская идентичность».

Выявлено, что гражданская идентичность это отождествление себя с сообществом граждан национально-государственного образования или феномен сознательного и активного гражданства, осознание себя членом гражданского общества. Часто гражданская идентичность рассматривается как компонент территориальной идентичности.

Выявлено, что для формирования граж- 
данской идентичности нужно сформировать следующие структурные компоненты: когнитивный (познавательный), эмоциональнооценочный, ценностно-ориентированный, деятельностный (поведенческий).

Авторы статьи представили разработанную тренинговую программу «Я - сознательный украинец», цель которой - способствовать становлению гражданской идентичности в подростковом возрасте через осознание собственной принадлежности к своему народу и развитие толерантности к другим народам. После детального изучения существующих программ были выбраны оптимальные методы: арт-терапия, дискуссия, психогимнастика, медитации-визуализации, ролевая игра, деловая игра, элементы психодрамы и социодрамы.

Ключевые слова: нация, группа, гражданство, гражданская идентичность, идентичность, социальная идентичность, толерантность, ценности. 